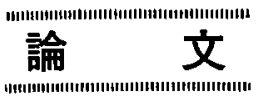

\title{
固体反応論への粒度分布の導入*
}

$$
\text { 佐々 宏** }
$$

\section{Introduction of Particle Size Distribution into Solid-State Reaction Kinetics}

by

\author{
Hiromu SASAKI
}

(Research Laboratory, Wireless Division, Matsushita Electric Industrial Co. Ltd., Osaka)

\begin{abstract}
An attempt made to intrcduce particle size distribution (PSD) into Carter's equation on solid-state reaction kinetics is herein reported. The PSD introduced into this equation is described as follows : the solid particles to participate in solid-state reaction are sorted into groups $n$ in number, each group consisting of particles of particular size range, and the sizes in each group being arranged in geometrical series. By thus introducing the PSD system into Carter's equations for the $n$-numberd groups, it is found possible to apply the over-all reacied fraction determined by quantative analysis mathematically to the rexcted fractions for each group. Carter's equation modified as above by the introduction of the PSD system has then been applied to the analysis of the reaction $\mathrm{PbO}+\mathrm{ZrO} \rightarrow$ $\mathrm{PbZrO}_{3}$. The measurements of PSD with the use of $\mathrm{ZrO}_{2}$ and the chemical determination of the over-all reacted fraction as a function of reaction time and temperature have recorded about $100 \mathrm{kcal}$ per mole as an activation energy for the reaction.
\end{abstract}

(Received May 20, 1964)

\section{1 緒言}

Jander が固体反応に関して一般によく知られた Jander の式を提唱して以来, 多くの固体反応がこの 式によって解析されてきた。一方これとは別の角度か ら固体反応が検討され．Jander の式とは異なるいく つかの速度論式も提出されている: 最近においては Carter が一つの速度論式を提出し，実騟と良い一致 を示したことを報告している。

以上のように固体反応に関していくつかの速度論式 があるが，てれらの理論の多くにはすべて共通の仮定 がはいっている，すなわち，反応にあずかる固体粒子 か，一定の半徍をもった球状粒子から成り立っている ことである.

Garter は，特にこの点を考慮し，彼の実驗では球 状の金属ニッケル粉末を特につくり，それを充分にふ るいでふるってはとんど同一粒经の粒子のみを使い， 典型的なモデル実験としてその酸化反応を検討した。

一般に固体粉末の粒经を揃える方法としては，タイ ラーのふるいによる分級法が多く用いられる。しかし， これによってもある程度の広がりを持った粒度分布は 避けられない，従来から固体反応に粒度分布を考慮し

- 原艘受理 昭和39年5月20日

・. 松下龟器産業(株) 無線事業本部研究所大欧府門具市1006
た例はきわめて少ない，ただ宮城が Jander の式に粒 度分布を分布関数の形で導入するととを武みているだ けである，筆者はこの点に注目し，粒度分布を具体的 に表わして速度論へ導入するととができるように考慮 した. 用いた速度論式は Carter の式である.一方， この粒度分布の導入法を奏際の固体反応， $\mathrm{PbO}+$ $\mathrm{ZrO}_{2} \rightarrow \mathrm{PbZrO}_{3}$ に適用した.

\section{Carter の速度論式}

Carter は, Jander の理論が二つの省略の上に立って

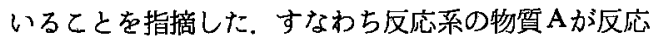
後Bになっても，それらの間には体積変化がないこと また，平行平面間の拡散に適用される式が基本になっ ている(したがって，Jander の式は反応率の低いと ころでのみ成立する）ことの二つである，てれらの点 を検討して次の速度論式を導いた，式の誘送の詳䋖は 原論文に倳る。

$$
\frac{Z-[1+(Z-1) x]^{2 / 3}-(Z-1)(1-x)^{2 / 3}}{2(Z-1)}=\frac{k}{r_{0}{ }^{2} t}
$$

ことでZは，反応にあずかる固体粒子の反応前と反応 後の体積比である。すなわち生成物が反応前の状態に 比べて，その比体積が何倍になったかる表わす係数で ある， $x$ は系全体の反応率， $k$ は反応速度定数， $r_{0}$ は 反応前の固体粒子の半经, そして $t$ は反応開始後の経 
過時間である. Carter はこの速度論式が，金属ニッ ケル粒子の酸化反応にきわめて良く適合することを示 した.

\section{3 粒度分布の導入法}

いま反応にあずかる固体粒子がある粒度分布をもって いて，その粒子集団が粒徍の大小にようてn個のグル ープから成り立っていると仮定する．各グループ内で の平均粒徍を ${ }_{1} r_{0},{ }_{2} r_{0}, \cdots \cdots \cdots \cdots_{n} r_{0}$ とし，そのグループ 亿属する粒子が集団全体の中で占める割合を $m_{1}, m_{2}$, ……..., $m_{n}$ する. 一方反応時間 $t$ 後における反応率 は, 各グループによって当然異なるはずであるから， それらを $x_{1}, x_{2}, \cdots \cdots \cdots, x_{n}$ とする. したがって, 次 の関係が成立する。

$$
\begin{array}{ll}
\sum_{1}^{n} & m_{n}=1 \\
\sum_{1}^{n} & m_{n} x_{n}=x
\end{array}
$$

とてでメは系全体の反応率である．各グループの粒径 の採り方は，实際のふるいによる分級と，計算に便利 であるととを考慮し，次のように等比級数の形に設定 した.

$$
{ }_{1} r_{0},{ }_{2} r_{0}\left(=a_{1} r_{0}\right), \cdots \cdots \cdots,{ }_{n} r_{0}\left(=a^{\mathrm{n}-1}{ }_{1} r_{0}\right)
$$

とてで、は1亿近く，1よりわずかに大きい定数であ ろ. $a$ が1に近いほど，粒度分布の表わし方としては 正確になる。しかし，そ机伴ってnが大になり計算 が複雑になる。タイラーの $2^{1 / 4}$ シリーズのるるいに 準ずれば $a$ は約 1.2 である。

さて，上に述べた粒度分布をそれぞれのグループの Carter の式に導入する.

$$
\begin{aligned}
& 1 \text { ร゙ループ } \frac{Z-\left[1+(Z-1) x_{1}\right]^{2 / 3}-(Z-1)\left(1-x_{1}\right)^{2 / 3}}{2(Z-1)} \\
& =\frac{k}{{ }_{1} r_{0}{ }^{2}} t \\
& 2 \text { グループ } \frac{Z-\left(1+(Z-1) x_{2}\right)^{2 / 3}-(Z-1)\left(1-x_{2}\right)^{2 / 3}}{2(Z-1) .} \\
& =\frac{k}{a^{2} r_{0}{ }^{2}} t \\
& =\frac{k}{a^{2(t-2){ }_{1} r_{0}} t} \\
& i \text { グループ } \frac{Z-\left[1+(Z-1) x_{i}\right]^{2 / 3}-(Z-1)\left(1-x_{i}\right)^{2 / 3}}{2(Z-1)} \\
& =\frac{k}{a^{2(i-1)}{ }_{1} r_{0}^{2}} t \\
& n \text { ท゙ループ } \frac{Z-\left(1+(Z-1) x_{n}\right)^{2 / 3}-(Z-1)\left(1-x_{n}\right)^{1 / 3}}{2(Z-1)}
\end{aligned}
$$

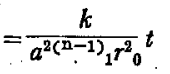

反応開始後, 時間 $t$ 亿おいて 1 i-1 グループまでは すでに反応が完了し，i〜nグループまではまだ完了し ていないとする. すなわち $x_{1}=x_{2}=\cdots \cdots \cdots . . .=x_{i-1}=1>$ $x_{i}>x_{i+1}>\cdots \cdots \cdot>x_{n}>0$ である. 反応開始後 $t$ までの間

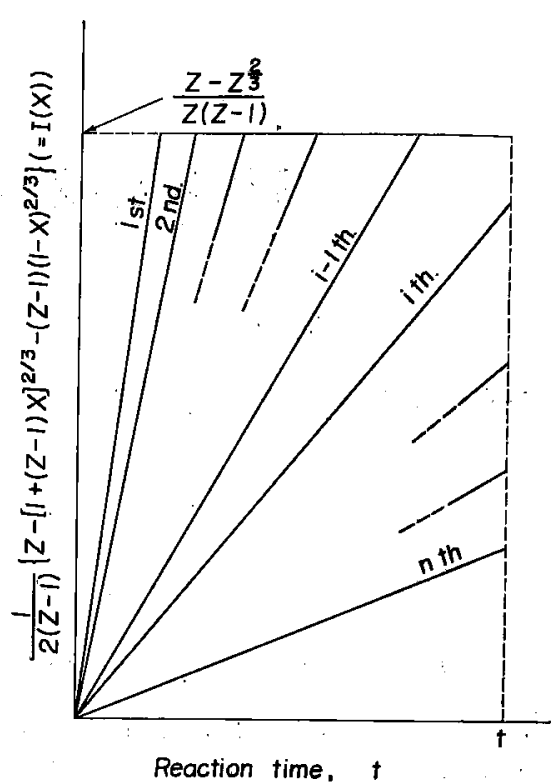

Fig. 1. Schematic $I(x)$ 's for each group as a function of reaction time.

の(5) (9)式の左辺の時閪的変化は Fig. I のようにな る.とれらの申で $て n$ グループまではそれぞれーつ の直線で表わされるので，それらの直線を重畳すると とによってもまた一つの新らしい直線が得られ，それ は次式によって表わされる。

$$
\begin{gathered}
\frac{1}{2(Z-1)} \frac{\left(a^{2}-1\right) a^{2(n-1)} n}{a^{2(n-t+1)}} \sum_{i}^{n}\left\{Z-\left(1+(Z-1) x_{n}\right)^{2 / 3}\right. \\
\left.-(Z-1)\left(1-x_{n}\right)^{2 / 3}\right\}=\frac{k}{{ }_{1} r_{0}^{2}} t
\end{gathered}
$$

一方, 全系の反応率 $x$ は

$$
x=\sum_{1}^{i-1} m_{n}+\sum_{i}^{n} m_{n} x_{n}
$$

である. (5)〜 (9)式の左辺をそれだれ $I\left(x_{1}\right), I\left(x_{2}\right), \cdots \cdots$ $I\left(x_{i-1}\right), I\left(x_{i}\right), \cdots \cdots I\left(x_{n}\right)$ ど表わすと，反応時間 $t$, 全

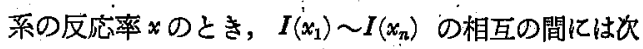
の関係が成立している.

$$
\begin{aligned}
& I\left(x_{1}\right)=I\left(x_{2}\right)=\cdots \cdots \cdots=I\left(x_{i-1}\right)=\frac{Z-Z^{2 / 3}}{2(Z-1)} \\
& \frac{Z-Z^{2 / 3}}{2(Z-1)}>I\left(x_{i}\right)=a^{2} I\left(x_{i+1}\right)=\cdots \cdots \cdots \\
& \cdots \cdots \cdots=a^{2(\mathrm{n}-i)}, I\left(x_{n}\right)
\end{aligned}
$$

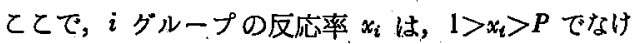
ればならないた烧し，Pは次の方程式の解である。

$$
\begin{array}{r}
\frac{Z-Z^{2 / 3}}{a^{2}}=Z-(1+(Z-1) x)^{2 / 3} \\
-(Z-1)(1-x)^{2 / 3}
\end{array}
$$

とてで $a=1.2, Z=2$ とすれば $p=0.936$ である， $x_{i}$ 〜 $x_{n}$ は(18)式によって互に関係づけられているが，同 時に(11)式をも満足するるのでなければならない，しか 
しながら，実際問題として(11)式と(19)式から $x_{i}$ を求め ろ方法法非常に複雑である。.つまり $1>x_{i}>p$ の条件 を満たす $x_{i}$ を任意にとり (18)式汃らそれに対応する $x_{i+1}$, $x_{i+2}, \cdots \cdots, x_{n}$ 求め，それらが(11)式と両立するか 否かを確めなければならないからである。 与えて $I\left(x_{i}\right)$ を計算することは簡単であるが，I( $\left.x_{i+1}\right)$, $\cdots \cdots, I\left(x_{n}\right)$ 加ら $x_{i+1}, \cdots \cdots, x_{n}$ をそれそれ求めるの は通常の計算方法ではむゔかしい，したがって，Fig. 2 に示すような $x$ とI $I(x)$ の関係を表わした図表をつ

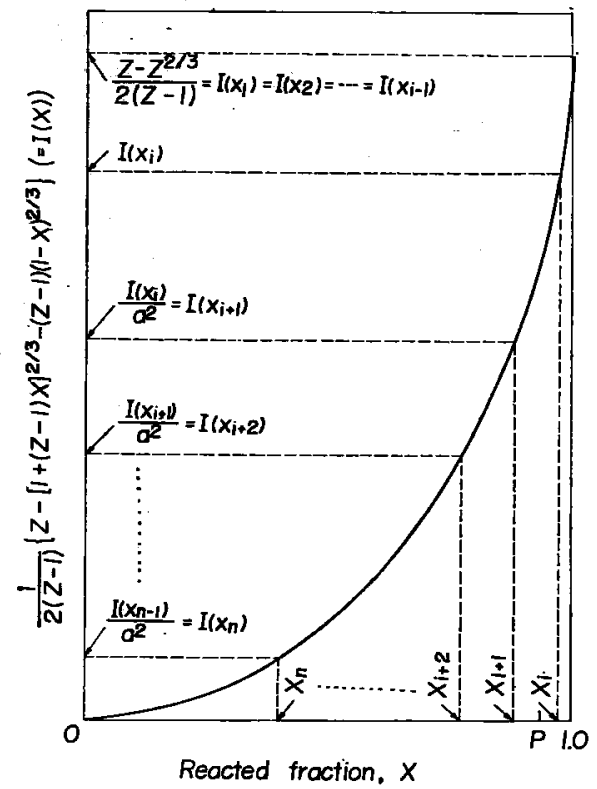

Fig. 2. Relation between reacted fraction and $I(x)$, and determination procedures of $x_{i+1} x_{n}$ based on $x_{i}$ arbitrarily fixed.

くり，てれから $x_{i+1} \cdots \cdots \cdots \cdot x_{n}$ を求める方が簡単であ る. $I\left(x_{i}\right) \sim I\left(x_{n}\right)$ の間には相互に(1)式の関係があるの で，任意㹸与えた $x_{i}$ から Fig. 2 亿示されている手 順で， $x_{i+1}, x_{i+2}, \cdots \cdots x_{n}$ が図的佂求められていく，そ しててれらの值が(11)式を满足すれば(10)式が具体的に計 算でき，各反応温度，時間における反応速度定数 $k か$ 定まる，ての $k$ の温度依存性汃ら，活性化エネルギを 求める手順は通常の方法之同じである.

4 固体反応, $\mathbf{P b O}+\mathrm{ZrO}_{2} \rightarrow \mathbf{P b Z r O}_{3}$ への適用 との反店過程においては， $\mathrm{PbO}, \mathrm{ZrO}_{2}, \mathrm{PbZrO}_{3}$ 以外 の結晶相はX線解析の結果みられなかったので，炊の 反応方程式によって順次反応率が増加していくものと 考光た。

$\mathrm{PbO}+\mathrm{ZrO}_{2}=x \mathrm{PbZrO}_{3}+(1-x) \mathrm{PbO}$

$$
+(1-x) \mathrm{ZrO}_{2}
$$

\section{$4 \cdot 1$ 拉度分布の測定}

次述べる二つの仮定から， $\mathrm{ZrO}_{2}$ 粉末のみの粒度分
布を測定した．まず第一には， $\mathrm{PbO} と \mathrm{ZrO}_{2}$ の等モル 混合物を数百 $\mathrm{kg} / \mathrm{cm}^{2}$ の圧力でペレット状成型する とき，やわらかい $\mathrm{PbO}$ は $\mathrm{ZrO}_{2}$ 粒子の周囲でつぷれ， 完全に $\mathrm{ZrO}_{2}$ 粒子をおおうようになると考える。第

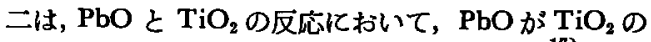
側へ移動して $\mathrm{PbTiO}_{3}$ を生ずるという聅験事拝汃ら推 論して，いまの場合も $\mathrm{PbO}$ が $\mathrm{ZrO}_{2}$ の側向って拡 散し $\mathrm{PbZrO}_{3}$ を生ずるとする。したがって，反応の 律速段階は生成した $\mathrm{PbZrO}_{3}$ 層内での $\mathrm{PbO}$ の拢散 であると考える。

$\mathrm{ZrO}_{2}$ 粉末の粒度分布列定は 通常の沈降法によった。 液媒は水で，0.2\%のへキサメ夕燐酸ソーダを加えて 充分に分散させた後測定した，2回の測定結果はよい 一致を示したので，各粒子の属するグループの決め方 としては炊の関係式によった。

$$
\begin{aligned}
\frac{2 a^{i-1}{ }_{1} r_{0}}{1+a}<i \text { グループに属する粒子の半徍 } \\
<\frac{2 a^{4}{ }_{1} T_{0}}{1+a}
\end{aligned}
$$

この最大および最小粒径の算術平均 $a^{i-1}{ }_{1} r_{0}$ はになって いる. 用いた $\mathrm{ZrO}_{2}$ 粉末は比較的広い粒度分布 (0.5〜 $10 \mu)$ をるっていたので, $a=1.2$ として $n=20,{ }_{1} r_{0}=0.31 \mu$, ${ }_{20} r_{0}=9.8 \mu$ とした．测定の結果得られた粒度分布を Table I に示す.

\begin{tabular}{|c|c|c|c|}
\hline Group No. & Range of size $(\mu)$ & $\begin{array}{c}\text { Mean size } \\
(\mu)\end{array}$ & $\begin{array}{c}\text { Fraction } \\
(\%))\end{array}$ \\
\hline 1 & $0.28 \sim 0.33$ & 0.31 & 0.1 \\
\hline 2 & $0.33-0.40$ & 0.37 & 0.2 \\
\hline 3 & $0.40 \sim 0.48$ & 0.44 & 0.4 \\
\hline 4 & $0.48 \sim 0.58$ & 0.53 & 0.8 \\
\hline 5 & $0.58 \sim 0.69$ & 0.64 & 1.4 \\
\hline 6 & $0.69 \sim 0.83$ & 0.76 & 2.5 \\
\hline 7 & $0.83-1.00$ & 0.92 & 4.5 \\
\hline 8 & $1.00-1.20$ & 1.10 & 9.5 \\
\hline 9 & $1.20 \sim 1.40$ & 1.30 & 14.4 \\
\hline 10 & $1.40 \sim 1.70$ & 1.55 & 22.4 \\
\hline 11 & $1.70 \sim 2.10$ & 1.90 & 17.5 \\
\hline 12 & $2.10 \sim 2.50$ & 2.30 & 7.7 \\
\hline 13 & $2.50 \sim 3.00$ & 2.75 & 4.8 \\
\hline 14 & $3.00 \sim 3.60$ & 3.30 & 4.5 \\
\hline 15 & $3.60 \sim 4.30$ & 3.95 & 3.4 \\
\hline 16 & $4.30 \sim 5.20$ & 4.75 & 2.3 \\
\hline 17 . & $5.20 \sim 6.20$ & 5.70 & 1.5 \\
\hline 18 & $6.20 \sim 7.40$ & 6.80 & 1.2 \\
\hline 19 & $7.40 \sim 8.90$ & 8.15 & 0.6 \\
\hline 20 & $8.90 \sim 10.70$ & 9.80 & 0.3 \\
\hline
\end{tabular}

Table I. Particle size distribution of $\mathrm{ZrO}_{2}$ powders. 


\section{2 反応条件および反応率}

$\mathrm{PbO}$ と $\mathrm{ZrO}_{2}$.の等モル混合物を直徍 $25 \mathrm{~mm}$ ，厚さ $4.5 \mathrm{~mm}$ のペレット状に $800 \mathrm{~kg} / \mathrm{cm}^{2}$ の圧力で成型し, $650,675,700,725,750,800^{\circ} \mathrm{C}$ の各温度で所定の時 間反応させた，反応率は(15)式によって未反応のまま牫 っている PbO を酢酸で抽出し, EDTA で滴定して 定量した. Fig. 3 とこれらの結果を示す。

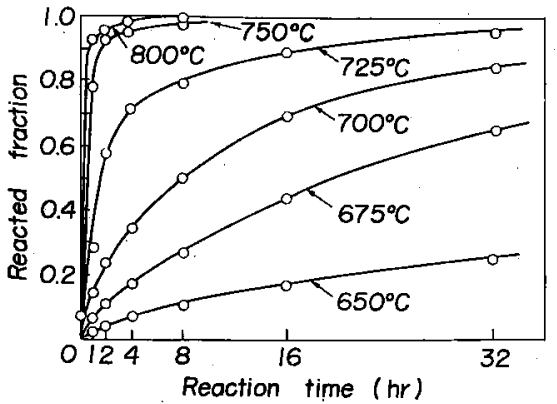

Fig. 3. Reacted fractions as a function of reaction time at various temperatures for the reaction $\mathrm{PbO}+\mathrm{ZrO}_{2} \rightarrow \mathrm{PbZrO}_{3}$.

\section{3 粒度分布上反応率の導入}

ての系での 反応は $\mathrm{ZrO}_{2}$ が $\mathrm{PbZrO}_{3}$ 亿変わると考 えてよいので, $\mathrm{ZrO}_{2}$ の比体積と $\mathrm{PbZrO}_{3}$ のそれとの 比が $Z$ 亿対応することになる。 ての場合 $Z=2.0$ で, 計算上きわめて好都合である， $Z=2.0$ を(1)式代入 すると

$1-\frac{(1+x)^{2 / 3}}{2}-\frac{(1-x)^{2 / 3}}{2}=\frac{k}{r_{0}^{2}} t$
となる. Table I 亿示されている I〜20 グループの そ机ぞれ代(17)式を与充，それらの式から(10)式に相当す る式をつくると

$$
\begin{aligned}
4.64 \times 10^{-10} \times 1.44 \sum_{i}^{20} & \left\{2-\left(1+x_{n}\right)^{2 / 3}-\left(1-x_{n}\right)^{2 / 2}\right] \\
=k t & \ldots .
\end{aligned}
$$

となる。こてで粒徍の単位は $\mathrm{cm}$ を採用している，反 応率と反応時間加ら，(11)式と(18)式を使って反応速度定 数 $k$ を計算するととは非常仁むづかしいので図表解 法によるととにした．まずその図表をつくるために Table I の粒度分布を(11)式に入れ，それと(18)式とを使 って任意に与えた反応率に対応する $k t$ の值を計算し た。 ての任意に与える反応率を細かくしかる数多く与 えて計算するほど，正確な図表になるので，iグルー プの反応率としては $0.98 ， 0.96,0.936 の 3$ 種類を選 んだ. てれらの反応率に対応する $1 \sim i-1$ グループの

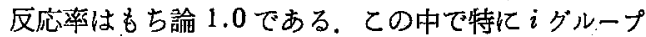
の反応率が 0.936 というととば，i-1グループが時 間 $t$ で丁度反応が完了した状態に対応する. 上の 3 種 類の $x_{i}$ の中で $x_{i}=0.98$ を用いる計算を例にとって 説明すると，てれに対応する各グループの反応率は $x_{i+1}=0.891, x_{i+2}=0.783, \cdots \cdots \cdots$ と計算できる。就でで $i=1, i=2, \ldots \ldots \ldots . i=20$ と変化させながら(11)式を使っ て20個の全系の反応率を求める：ての20倜の $x$ で住低 い反広率を表わすととができないので， $x_{i}=0.891$ ， $x_{i}=0.783 \cdots \cdots \cdots$..... 順に移動していって低い $x$ を表わす ことができるようにする．同様の方法を $x_{i}=0.96, x_{i}$ $=0.936$ についても行なう。これらの計算方法の一部を

Table II. Calculation procedures for figuring (In each series, No. $4 \sim 17$

\begin{tabular}{|c|c|c|c|c|c|c|c|}
\hline \multicolumn{8}{|c|}{0.98 Series } \\
\hline Group No. & $\begin{array}{l}\text { CaIculation } \\
\text { No. } 1\end{array}$ & No. 2 & No. 3 & …................. & No. 20 & No. 21 & ...... \\
\hline 1 & $x_{1}=1.00$ & 1.00 & 1.00 & $\ldots \ldots \ldots \ldots \ldots \ldots$ & 0.98 & 0.891 & …............... \\
\hline 2 & $x_{3}=1.00$ & 1.00 & 1.00 & ................. & 0.891 & 0.783 & 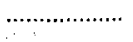 \\
\hline 3 & $x_{8}=1.00$ & 1.00 & 1.00 & n................... & 0.783 & 0.675 & : \\
\hline $\begin{array}{c}\cdots \\
\vdots \\
\vdots \\
\vdots \\
\vdots\end{array}$ & $\begin{array}{l}\vdots \\
\vdots \\
\vdots\end{array}$ & $\vdots$ & $\vdots$ & $\begin{array}{c}\vdots \\
\vdots \\
\vdots \\
\vdots\end{array}$ & $\begin{array}{l}\vdots \\
\vdots \\
\vdots\end{array}$ & $\begin{array}{l}\vdots \\
\vdots \\
\vdots \\
\vdots\end{array}$ & $\vdots$ \\
\hline 18 & $x_{18}=1.00$ & 1.00 & 0.98 & n................ & 0.057 & 0.048 & (n.................... \\
\hline 19 & $x_{1 \mathrm{\theta}}=1.00$ & 0.98 & 0.891 & $\ldots \ldots \ldots \ldots \ldots \ldots$ & 0.048 & 0.040 & (...................... \\
\hline 20 & $x_{20}=0.98$ & . 0.891 & 0.783 & n................ & 0.040 & 0.033 & $\ldots \ldots \ldots \ldots \ldots$ \\
\hline$\sum_{1}^{20} m_{n^{x_{n}}}$ & 0.9999 & 0.9996 & 0.9984 & $\cdots \cdots$ & 0.2455 & 0.2057 & . $\ldots \ldots \ldots \ldots \ldots \ldots$ \\
\hline$\sum_{i}^{20} I\left(x_{n}\right)$ & 0.1747 & 0.2960 & 0.3803 & $\cdots$ & 0.5711 & 0.3965 & …................. \\
\hline$\sum_{i}^{20} \frac{1}{n^{r} a^{9}}$ & $1.053 \times 10^{6}$ & $2.567 \times 10^{6}$ & $4.754 \times 10^{\circ}$ & , $\ldots \ldots \ldots \ldots \ldots \ldots$ & $3.516 \times 10^{\circ}$ & $3.516 \times 10^{9}$ & (n...... \\
\hline$k t$ & $1.659 \times 10^{-7}$ & $1.152 \times 10^{-7}$ & $8.000 \times 10^{-8}$ & 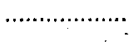 & $1.624 \times 10^{-10}$ & $1.128 \times 10^{-10}$ & ........... \\
\hline
\end{tabular}
groups and calculations No. 4 19 and $22 \sim 28$ are omitted.). 


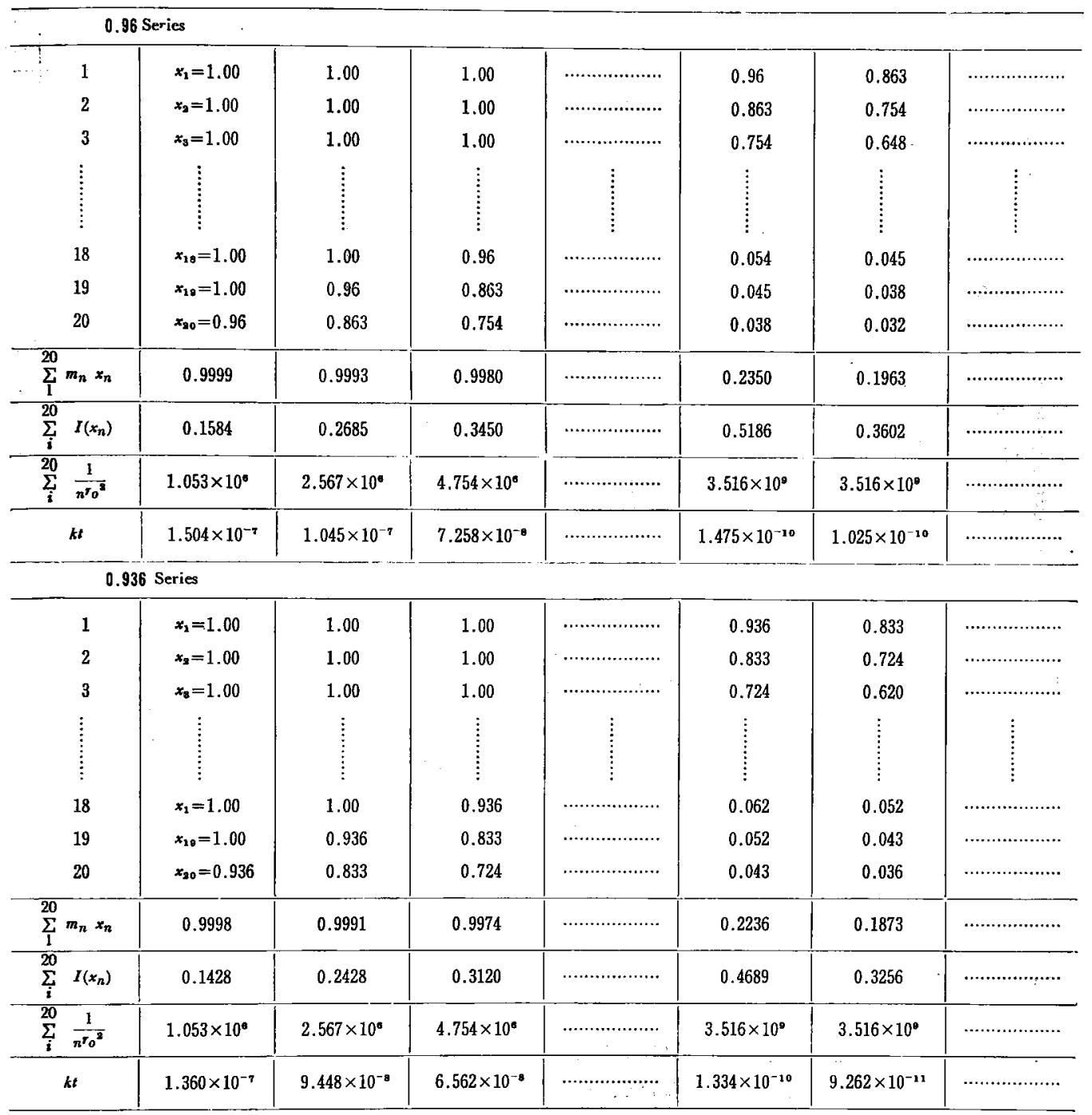

Table II にまとめた.上述の 3 種類の反応率 $0.98,0.96$, 0.936 をそれぞれ使って得られる系全体の反応率の系 列虎，各0.98シリーズ，0.96シリーズ，0.936シリー ズと名付けてある、これらの計算のすべての結果を図 表で表わしたのが Fig. 4 の kt とxの関係である. との図表を用いると，反応率 $x$ と反応㭙間 $t$ からそ の温度における $k$ の值が直接求まる．Fig. 3 亿示さ れている各反応温度, 各反応時間における反応率を用 い，それらの実験条件下における反応速度定数 $k$ を求 めた。 それらの值を Fig. 5 亿示す. 同一温度におけ る $k$ の值が反応時間によって若干異なるが，それら の平均値をもってその反応温度における $k$ とした，乙 の $k$ A Arrhenius plot $か ら, \mathrm{PbO}+\mathrm{ZrO}_{2} \rightarrow \mathrm{PbZrO}_{3}$ の反応の活性化エネルギを求めると $102.8 \mathrm{Kcal} / \mathrm{mole}$ であった。

\section{5 考察}

粒度分布導入の意義であるが，Carter の式をも含 めて，従来から提唱されている速度論のモデルは，一 定半堡をむった球状粒子から成り立っている，したが って，てれらの条件からはずれる場合には，政密に言 っていずれの速度諭も適用できないととになる。先際 問題としては粒度分布をもった固体粒子を用いて反応 させることが多いのであるから，むしろ現実の状態に 近い形で速度論的な検討をするととが大事であると考 えられる，その第一歩としての本論文に逨べられた粒 度分布の導入法は，具体的に速度論的な計算を可能な らしめたと言える. 特に筧業上，化兴工業上，ほとん

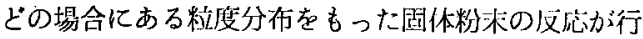

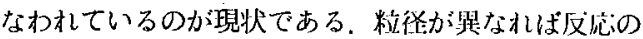

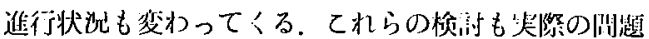
と關連して重要なととである。こころみに Carter の 


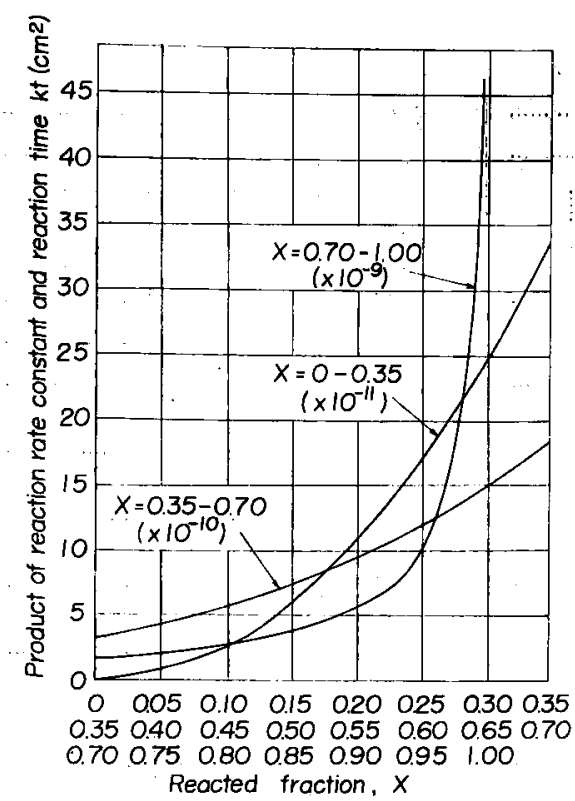

Fig. 4. Product of reaction rate constant and reaction time, as a function of reacted fraction for the reaction $\mathrm{PbO}+\mathrm{ZrO}_{2} \rightarrow$ $\mathrm{PbZrO}_{3}$.

式だ計算した，粒径と反応率の関係を Table III にま とめてみた: Table III では粒径が1.00の粒子が度 反応を完了したときに，それよりも大きい粒子はどの 程度の反底率を示すかる表わしている。

粒度分布の導入法を実際の固体反応， $\mathrm{PbO}+\mathrm{ZrO}_{2}$ $\rightarrow \mathrm{PbZrO}_{3}$ に適用した效果であるが， Table II にも示 されているように，本反応に使用された $\mathrm{ZrO}_{2}$ 粉末は かなり広い範囲にわたった精度分布をもっている。し たがって，上にも述べたように，てれらの粒度分布を 無視して速度論的な取り报いをするととは䈗密に言っ て間違いであるが，粒度分布を導入した效果を知るた めに，あえて Table II の粒度分布の中から最も分布 の多い粒隹として $r_{0}=1.55 \mu$ を選び，てれをもって $\mathrm{ZrO}_{2}$ 粉末の粒隹として計算した結果, 各反応温度に わける反応速度定数 $k$ の一定性は, 粒度分布を導入し た場合と比較してかなり瑟くなっている。とのととか ら，同じ速度論式を使っても最初に理論を立てたとき のモデルに近付けた形で考えた粒度分布導入法は， $I(x)$

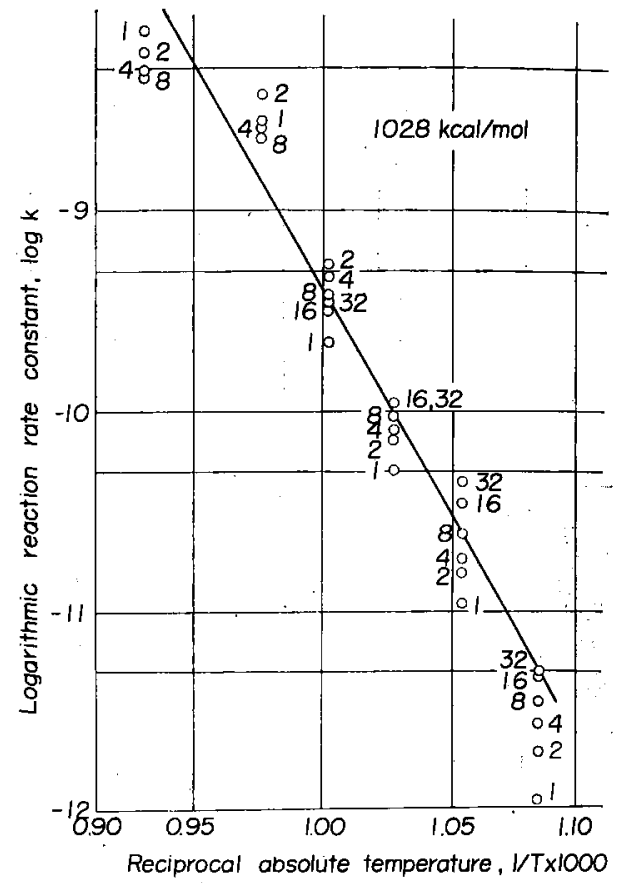

Fig. 5. Arrhenius plot of reaction rate constants at various reaction temperatures and times, and activation energy for the reaction $\mathrm{PbO}+\mathrm{ZrO}_{2} \rightarrow \mathrm{PbZrO}_{3}$ (numbers : reaction time).

と $t$ の直線性をかなり改善していると言える。

次に固体反応の速度論的研究に刘して，本論文で取 り上げた $\mathrm{PbO}+\mathrm{ZrO}_{2} \rightarrow \mathrm{PbZrO}_{3}$ なる反応がモデル央 験として適当かどうかの問題がある，まず， $\mathrm{ZrO}_{2}$ 粒 子の周囲が完全に PbOによっておおうわれるうにす るために，PbO と $\mathrm{ZrO}_{2}$ の充分な混合状態を実現さ せなければならない，そのためのかく䢁混合操作は両 者の混合状㦘を良くし，さらに，粒形を球状に近付け る意味から非常に重要なととであるが，との操作の過 程で粒度分布の変化もまた起とり得るととを考虑して おく必要がある，PbO と $\mathrm{ZrO}_{2}$ の混合物は，酢酸处 理によって PbO のみを溶解除去することが可能であ るが，混合後に分離ができない場合にはあらかじめ粒 度分布を測定しておかなくてはならない，したがって， 混合操作の過程で若干の粒度分布の变化はまねがれな い. との点に関して, Garter の行なった金属ニッケ

Table III. Reacted fractions depending on particle sizes, calculated by Carter's equation assuming $Z=2.00$.

\begin{tabular}{l|c|c|c|c|c|c|c|c}
\hline Particle sizc & 1.00 & 1.20 & 1.44 & 1.73 & 2.07 & -2.49 & $\ldots \ldots \ldots \ldots$ \\
\hline Reactcd fraction $(\not 6)$ & 100 & 93.5 & 83.5 & 72.0 & 61.7 & 52.3 & $\ldots \ldots \ldots \ldots$ \\
\hline
\end{tabular}


ル粒子の酸化反応はとのような問題がないため，モデ ル実験としても取り扱いやすい反応である.

さて Fig. 5 を見ろと，反応速度定数 $k$ かi同一温度 でありながら，反応時間によってある程度異なった值 を示しているのがわかる。もしも，理論と実験が調和 すれば，当然反応時間とは然関係に $k$ は一定值になる はずである. 実験結果によれば， $k$ の值の㑯向は低温 でしかも反応時間が短いほど小さい，すなわち，反応 率が低いときに小さくなりやすい傾向を示している. とれに対する一つの理由としては，反応率の決定を化 学分析によっているととが考光られる.つまり反応率 は未反応の $\mathrm{PbO}$ を酢酸抽出して定量し，それと最初 の $\mathrm{PbO}$ の全量との差として求めている. 低温, 短時間 の反応では $\mathrm{PbZrO}_{3}$ の生成量が少なく，しかもその結 晶性が良くないために, 酢酸抽出の際に未反応状態で 残っている $\mathrm{PbO} と と も に わ す ゙ か に そ の ~ \mathrm{PbZrO}_{3}$ が溶 解するようである。したがって，反応率としては低く 算出され，その結果 $k$ の值も小さくなる傾向をもつも のと考えられる.

次に Fig. 1 の中で，もしも，1〜nの各グループ の $I(x) t$ との関係を表わす折れ線, 直楾をすべて重 ね合わせたとすると, 途中の時閒（1 グループが反応 を完了した時間) までは一つの直線として表わされる が，その後は $n$ 個の折れ曲り点をもった $n$ 個の直線の 連なりとなり，一見して曲線のように見えるようにな る。つまり直線性加らずれてくる。このことは粒度分 布をもった固体粉末の反応速度論的解析において，そ の粒度分布を省略して一つの粒径で代表させて行なっ た計算結果と同しととに対応する。このととは Jander の式を使った場合でも当然起てり得る現象である。一 般に固体反応の速度論的解析において, 反応率が大き くなるにつれて速度論式と時間の関係（本論文では $I(x) \sim t$ の関䋆) において直線性が悪くなることがし ばしば起こる，もち論，その速度論式が㚻当か否かに 6関係しょうが，粒度分布の省略もまた，直線関係を 悪くする一因となり得るととが予想される。

$$
6 \text { 結論 }
$$

(1)固体反心の速度論に関する Carter の式へ，次の定 義による粒度分布を導入して具体的な計算を進め得る ことを明らかにした。

(1反応にあずかる固体粒子が，その粒径の篹囲にし たがってn喊のグループから成り立っているとする。 (2)各ダループの平均粒佳は互に等比級数の関係にあ るようにする。

(3)各ク゚ループの固体粒子が全体に占める㓡合 (分率) を定める.

(4)各グルーブには粒徉に依侾する固有の反心率を还 義する。
(2)各グループに関する Carter の式，被搪散成分の粒 度分布, 全系の示す反店率を䌊合し, $n$ 個の Garter の式を末反応グループと既反度グルーブにわけて計算 をする。

(3)各反応温度における反応速度定数を求め, その温度 依存性から反応の活性化エネルギを求める.

(4)乙の粒度分布を導入した Carter の式を用いて PbO $+\mathrm{ZrO}_{2} \rightarrow \mathrm{PbZrO}_{3}$ の固体反応を解析し， $\mathrm{PbZrO}_{3}$ の生 成に要する活性化エネギが約 $100 \mathrm{Kcal} / \mathrm{mole}$ であるて とを明らかにした。

最後に本研究の逐行に際しては, 当研究所々長城阪 俊吉博士より絶えずで指導，でべん達をいただいた。 また当所部長岡崎千里博士には有意義なで討議を得た。 さらにX線解析では森課長に，粒度分布の測定，化学， 分析, 電子計算機による計算では, 松尾, 黒川, 藤村 山本各社員ので協力を得た，以上の方々に厚くお礼を 申し上げる次第である.

(昭和38年10月 7 日，第 1 回粉体仪関する討諭会にて講演)

\section{参考文 献}

1) Jander, W., Z. anorg. u. allgem. Chem., 163, 1 (1927).

2) Okamura, T., and J. Shimoirzaka, Sci. Rep. R.I.T.U., A2, 673 (1950)

3) 久保輝一郎, 神力喜一, 工化, 55, 49(1952); 56, 335 (1953).

4) Jorgensen, P.J., M.E. Wadsworth, and I.B. Cutler, J. Am. Ceram. Soc., 42, 613 (1959.)

5) Economos, G., and T.R. Clevenger, Jr., J. Am. Ceram. Soc., 43, 48 (1960).

6) Turner, W.E.S., J. Soc. Glass Tech., 17, 23 (1933).

7) Serin, B., and R.T. Ellickson, J. Chem. Phys., 9, 742 (1941).

8) Gibson, G., and R. Ward, J. Am. Ceram. Soc., 20, 239 (1943).

9) 瀬川 清, 窯協, 56, 59 (1948).

10) Ginstling, A.M., and B.I. Brounshtein, J. Appl. Ghem. (USSR), 23, 1327 (1950). (English translation p. 1327)

11) 神力喜-- 久, 久保輝一郎, 工化, 57, 619 (1954).

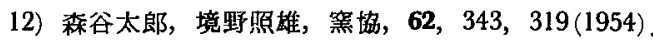

13) Carter, R.E., J. Chem. Phys., 34, 2010 (1961).

14) Carter, R.E., J. Cyem. Phys., 35, 1137 (1961).

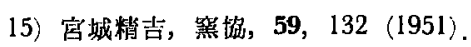

16) 投稿㸱1 (Hiromu Sasaki, "Introduction of Particle Size Distribution into Kinetics of Solid State Reaction", J. Am. Ceram. Soc.) 
17) 投稿中（Yoshihiro Matsuo, Hiromu Sasaki, "Formation of Lead Zirconate-Lead Titanate Solid Solutions", J. Am. Ceram. Soc.)
18）佐々木宏，第 I回粉体に関する討論会にて講演， 炤和38年10月 7 日 (於京都)。

19）平田蒬，老田冒弘（分析化学に投稿予定）. 